\title{
Physical and commuting characteristics of selected peri-urban settlements in Kaduna, Kaduna State, Nigeria
}

\author{
M. B. Usman ${ }^{1 *}$, Y. A. Sanusi ${ }^{2}$ and D. Musa ${ }^{2}$ \\ ${ }^{1}$ Department of Urban and Regional Planning, Kaduna Polytechnic, Kaduna State Nigeria. \\ ${ }^{2}$ Department of Urban and Regional Planning, Federal University of Technology Minna, Niger State Nigeria.
}

Received 12 April, 2017; Accepted 20 September, 2017

\begin{abstract}
Cities in Nigeria have been experiencing exceptional changes in terms of population and spatial extent. The rapid rate of these growths and the inadvertent expansion of cities have resulted in several negative consequences. This research is aimed at evaluating the physical and commuting pattern of selected peri-urban settlements. The objectives are to examine the availability of utilities, services and infrastructure; assess the physical and spatial characteristics; and appraise the commuting characteristics between the city and the peri-urban settlements. The research design adopted is the mixed research method which involves the investigation of patterns or sequences of growth and changes over a given period of time (time series), and the description of existing conditions in a given area. The results shows that the most used mode for commuting between the peripheral settlements and the city centre is the bus with $(24 \%)$, while the least is the lorry/trailer with a score of $(2.1 \%)$. The major factors of influence for the trips are work, with (23\%), while job seeking is the least with (3.5\%). The study also reveals that the peripheral areas of Kaduna metropolis suffer serious traffic congestion caused by increased number of private vehicles on inadequate road network with finite capacity, hence, the need to enforce compliance with basic development control standards, and the use of advanced technology such as trip matching and the internet for carpooling and ride sharing, thereby increasing the potential to reach the critical mass of users.
\end{abstract}

Key words: Peri-urban, traffic congestion, commuting, settlements.

\section{INTRODUCTION}

The urban fringe constitutes an important interface in settlement continuum and for a developing country such as Nigeria. It provides a buffer for people, urban physiology, and economy and in particular livelihood and services. The fringe is seen as the frontier in space where the returns to land from traditional and customary urban land uses are roughly equal to the returns from traditional and customary rural land uses (Sanusi, 2010). It is space located outside the limit of the city (Avram, 2009; Saxema, 2008). Such area reflects the pressure of

*Corresponding author. E-mail: babangida67@yahoo.com.

Author agree that this article remain permanently open access under the terms of the Creative Commons Attribution License 4.0 International License 
the city on the surrounding neighbouring space (Avram, 2009). The fringe is also characterised by random, separate, and fragmented growth (Alabi, 2009). Peripheral areas also mean an evolution or interaction zone, where both urban and rural activities lie contiguous to each other and landscape element changes rather rapidly, which are influenced largely by human actions (Douglas, 2006). These areas include protected areas, forested hills, conserved woodlands, major agricultural lands, and important wetlands, which are critical to the survival of the urban residents. Peri-urban area is not only a zone facing the direct effects of the land demands of urban expansion and pollution, it is also an inclusive market-related sphere of influence that is easily identifiable with respect to the handling of agricultural and natural resource harvests (Simon et al., 2006).

In economic term, the fringe is seen as a space where livelihoods depend on natural resources (Adesina, 2007). Hence, 'land is the characteristics to agricultural activities and the inhabitants' way of life is specifically rural' (Avram, 2007). As a result, people who reside in the fringes live in the economic realm of the city, but are not attracted to urban economy (Taleshi, 2009). Largely, fringe settlements 'develop outside of government control and do not follow strictly formal and traditional urban planning and development processes' (Hogrewe et al., 1993). The loss of arable agricultural land to urban growth in developing regions is flagged to be a result of prevalent anthropogenic activities. Similarly, the unprecedented transformation of natural landscapes into urban settings significantly affects the natural functioning of ecosystems. Hence, urbanization has been the foremost human led land-use anthropogenic activity with huge and irreversible impacts. It is a major force that drives changes such as land-use land-cover change (LULCC), biodiversity loss, the biogeochemical cycle, hydrological systems, and climate. Another prominent agent that can be linked to the unprecedented growth witnessed in urban expansion is population increase (Mahmoud et al., 2016).

The year 2008 has been celebrated globally as the year in which the percentage of the world's population living in towns and cities supersedes that of those living in rural areas (Mabogunje, 2008). In fact, the world has developed faster than initially predicted by Rev. Thomas Robert Malthus in 1798. "He argued that one day the population of the world would outstrip the globes ability to feed it", because population expanded geometrically, while subsistence increases only at an arithmetic ratio which could lead to societal ruins. In 1950, there were 86 cities in the world with a population of more than one million. Today, there are over 400 cities that are one million and above, and by 2015, this figure is expected to reach at least 550 and Africa has been the region with the fastest rate of urbanization in the world (Badiane, 2006). Cities in a country like Nigeria have been experiencing exceptional changes in terms of both population and spatial extent. The instruments for rapid city expansion in the developing countries are rural-urban migration and natural increase. In 1976, one third of the world population lived in cities and 30 years later (2006), this rose to one-half of the entire human kind (Tibaijuka, 2006) and by the target year for the Millennium Development Goals (MDG'S), cities in the world are expected to grow to two-third or 6 billion people by 2050 (UN Habitat, 2012; Aitieri et al., 2014).

Notwithstanding the economic benefits that comes with it; the rapid rates of growth and inadvertent expansion of cities have resulted in several negative consequences, especially in developing nations. These can be seen in the emergence of shanty's, illegal occupation of residential plots, increasing vehicular traffic congestion, worsening infrastructure and shortfalls in service delivery among others, which consequently contributes to land use change. The rate of urban growth and its encroachment into agricultural land use is unprecedented which is a popular trend and pattern in most countries (Belal and Moghanm, 2011; Long et al., 2007).

Rapid growth in urban areas which is expected to be pervasive for the ecological landscape of urban regions in developing nations will remain as one of the critical concerns of global change in the 21st century that will distress the human wellbeing. This increasing rate of urban growth and land use changes endangers the ecosystem of large cities in advanced countries and giving rise to many landscape and ecological challenges such as flooding, shortage in portable water and food supply, and negative microclimatic condition that are feared to impede sustainable human development (Liu et al., 2007; Wolch et al., 2014). As cities spread out into countryside advancing like waves on a beach, the land on the edge, be it farmland, grassland, or forest is converted to urban uses (Bryant et al.,1982). As land allocation speeds up in the peri-urban areas, a land market emerges with changes in land use, changes that have resulted into haphazard and uncontrolled growth in most metropolitan areas. These areas have grown in spatial extent and density manifested by natural expansion of extent of built-up areas to their immediate rural surroundings. In this case, most peripheral settlements in close proximity to the urban centres are facing urban expansion.

In this study, attention is focused on evaluating the physical and commuting pattern of selected peri-urban settlements. The objectives of this paper are to examine the availability of utilities, services and infrastructure; assessing the physical and spatial characteristics of the peri-urban settlements; and appraising the commuting characteristics between the city and the peri-urban settlements.

\section{METHODOLOGY}

\section{Study area}

Kaduna metropolis is located between Lat. N10 $23^{\prime}$ and $10^{\circ} 43^{\prime} \mathrm{N}$ 


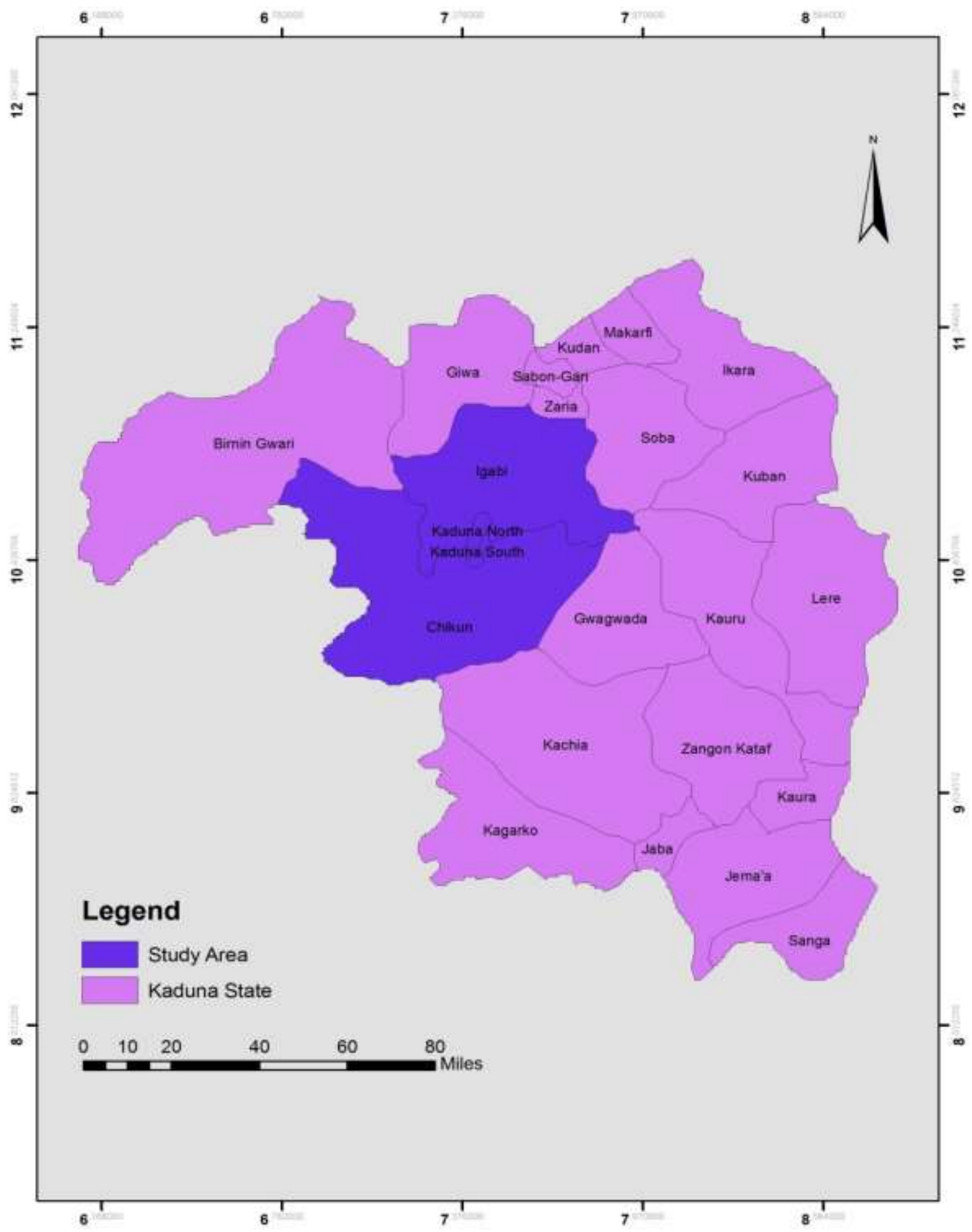

Figure 1. Kaduna metropolis.

and Long. $7^{\circ} 17^{\prime}$ and $7^{\circ} 37^{\prime} \mathrm{E}$. The study area is tightly drawn around Kaduna's developable area. The area consist of four Local Government Areas, namely: Kaduna North and Kaduna South, and parts of Igabi and Chikun Local Governments and about 12,347 $\mathrm{km}^{2}$ (Figure 1).
The core geology is mostly of the metamorphic rocks of the Nigerian Basement Complex. Weathering activities with fluvial erosion influenced by the bio-climatic nature of the environment have developed the characteristic high undulating plains with passive interfluves (Mortimore, 1970 cited in Umaru, 2006). 


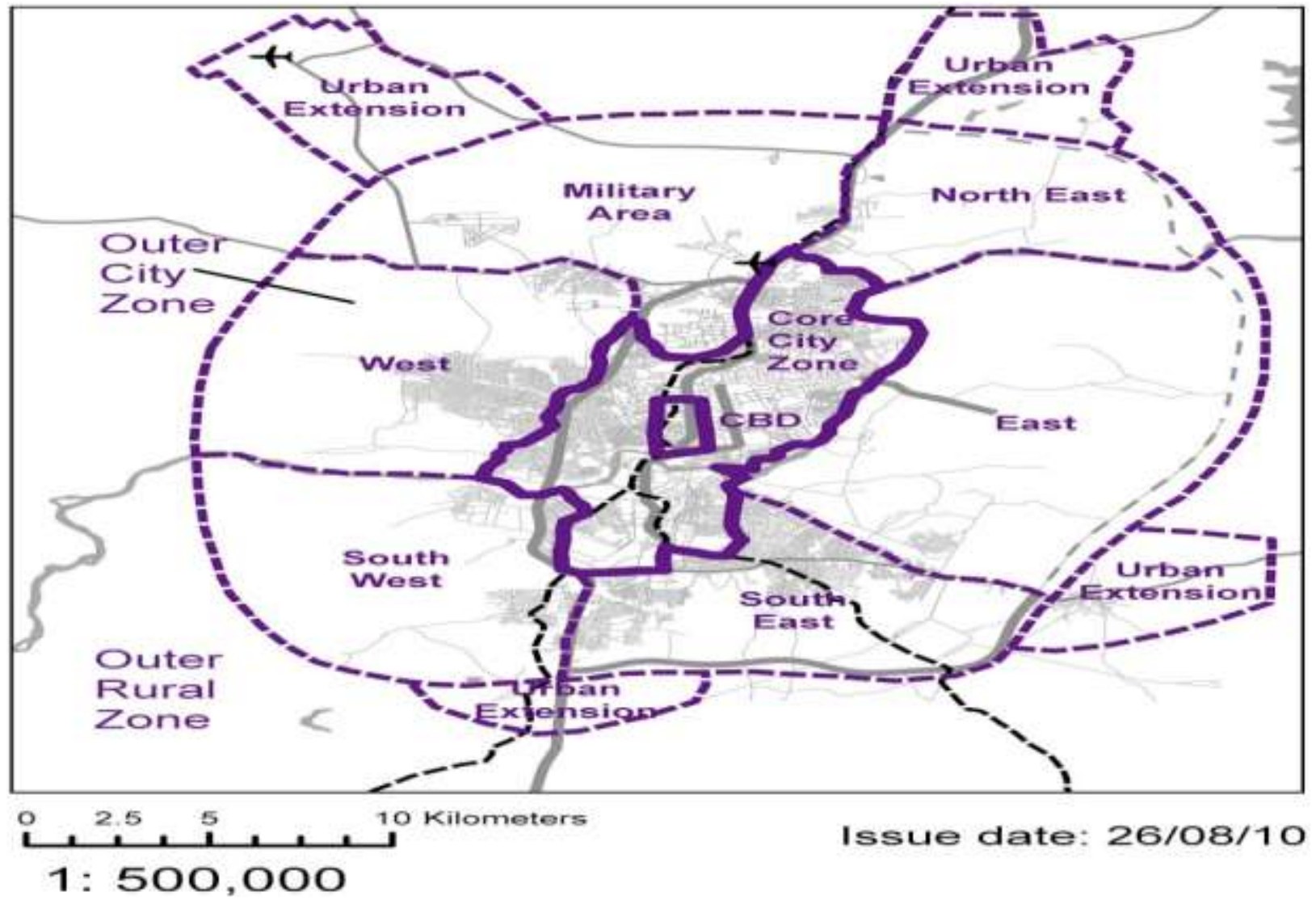

Figure 2. Kaduna extent of the metropolis and the peripheral areas. Source: Max Lock (1967).

However, the local relief of the area includes rocky granite residuals form inselberg of varying shapes and sizes. This could be found around the Kufena and Kagoro Hills and Dutsen WaiKudaru Ring complex standing out very conspicuously in the southern part (Ashafa, 2004).

The state forms part of the country's traditional melting pot (Ashafa, 2004). Among the major ethnic groups are the Hausa and Kurama to the North and Northeast, respectively. "Nerzit" is now used to refer to the Jaba, Kamuku, Gwari and Kadara in the West, Marwa and Chawai Kaje, Kaninkon, Koro, Kamanton, Kataf, in place of the disparaging term "Southern Zaria people". Similarly, the term "Hausawa" is used to refer to the people of Igabi, Ikara, Giwa and Makarfi LGAs, which are mostly inhabited by the "Maguzawas. In the north, they practice Islam but the majority of the people in the Southern LGAs profess Christianity (Kaduna State Newscope, 2004), the 2006 census provisional figures put the population of the state at 6,066,562 (National Population Commission, 2006).

The major sources of water in the urban areas are tap and wells. But there is acute water shortage in some of the neighborhoods' of the urban centres. In some cases, poorly treated or untreated water is released by the Water Board, periodically. In the rural areas, wells, boreholes, and streams are the major sources of water. These areas experience acute water problem during the dry season when the sources dry up. People trek long distances for water and much of what is gotten is not treated.

River Kaduna is the main source of water intake for domestic as well as industrial purposes in Kaduna metropolis. Over 50 functional industries depend on the river for their production processes through the Kaduna State Water Board with a capacity of 3,000,000 L per day (Bello, 2000).

In determining the spatial extent of the metropolis and the peripheral areas, the extent of the planning area (as provided by the Kaduna State Urban Planning and Development Authority) of $35 \mathrm{~km}$ radius will be used as the boundary of the study. The inner limit (built up areas) of $20 \mathrm{~km}$ radius as proposed by Max Lock (1967) shall form the basis for the work. Consequently, developments that exist between the extent of the built up areas, that is, $20 \mathrm{~km}$ radius as provided by Max Lock (1967) and the planning area forms the extent of the peripheral areas for the work (Figure 2).

The research design adopted for this work is the mixed research method (Developmental and Descriptive) which involves the investigation of patterns or sequences of growth and changes over a given period of time, and the description and interpretation of existing conditions in a given area. This is because the survey design proves to be effective in seeking the views of people on issues that affects them. The population for this study includes the population of the household heads in the sampled peripheral areas, National Space Research and Development Authority (NASRDA), National Centre for Remote Sensing (NCRS), National Population Commission (NPC, 2016) and Kaduna State Urban Planning and Development Authority (KASUPDA) (Figure 3).

The peripheral areas located in the four local government areas, namely; Rigachikun, Barakallahu, Kawo and Kawo New Extention, Sabon Gida, Rigasa, Hayin Danmani, Unguwan Gwari, Unguwan Kaji, Rafin Guza, Television village, Sabon Tasha, Narayi, Gonin Gora, Unguwan Romi, Mararraban Rido, Kudenda, Tsaunin Kura, Unguwan Gimbiya, Unguwan Boro, Unguwan Sunday, Nasarawa, 


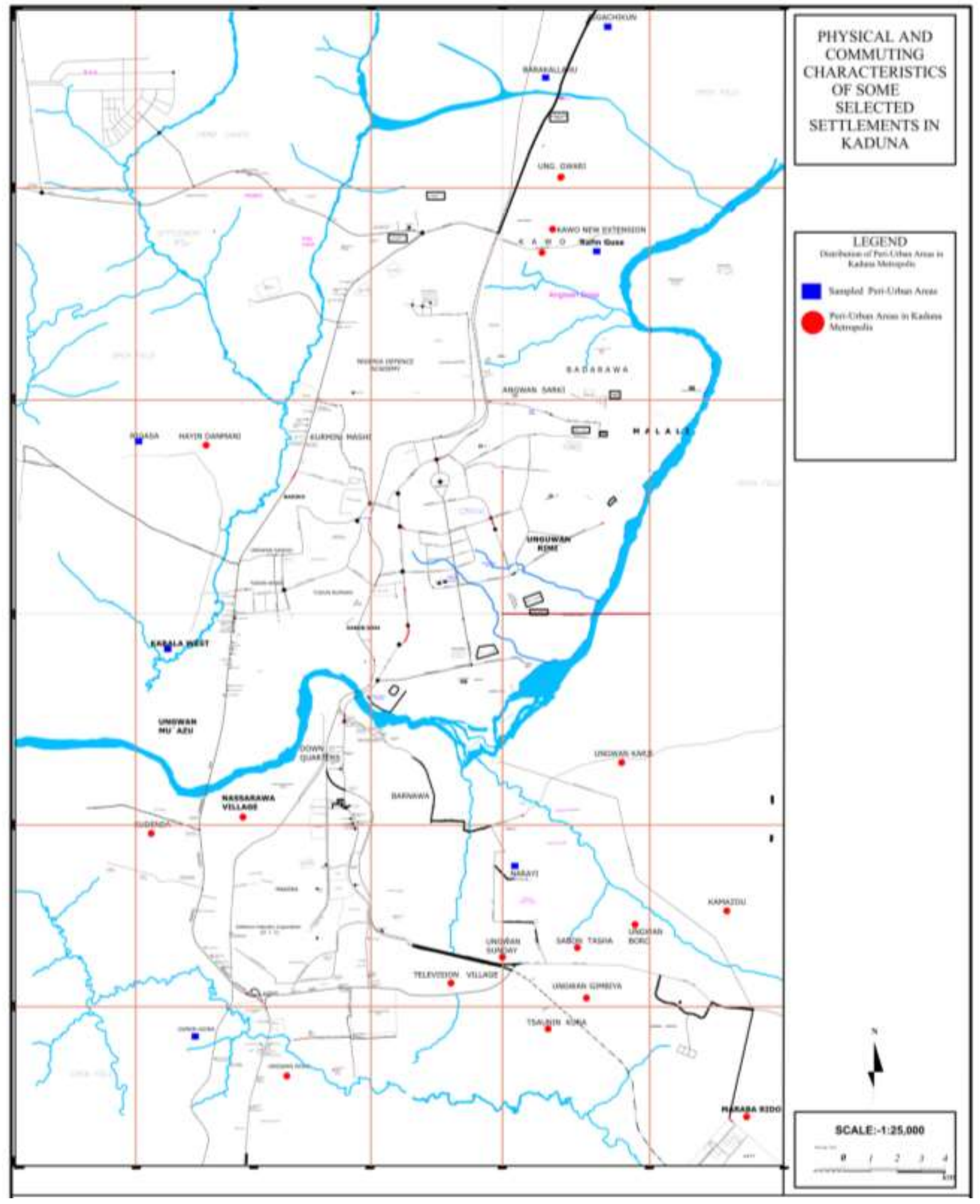

Figure 3. Distribution of peri-urban areas and the six sample settlements in Kaduna metropolis. 
Table 1. Distribution of population in the sampled settlements.

\begin{tabular}{|c|c|c|c|c|}
\hline Peripheral area & Population & Households & $\begin{array}{c}\text { Percentage of } \\
\text { total population }\end{array}$ & $\begin{array}{c}\text { Percentage of total } \\
\text { households }\end{array}$ \\
\hline Rigachikun & 15,238 & 1905 & 2 & 2 \\
\hline Barakallahu & 4,216 & 527 & 1 & 1 \\
\hline Rigasa & 149,600 & 18,700 & 22 & 22 \\
\hline Kawo & 21,352 & 2,669 & 3 & 3 \\
\hline Kawo N. Extension & 5,229 & 634 & 1 & 1 \\
\hline Hayin Danmani & 12,354 & 1,544 & 2 & 2 \\
\hline Sabon Gida & 2,150 & 269 & 0.3 & 0.3 \\
\hline Unguwan Gwari/Rafin Guza/Unguwan Kaji & 21,074 & 2,634 & 1 & 1 \\
\hline Unguwan Gimbiya & 3,293 & 412 & 1 & 1 \\
\hline Unguwan Boro & 5,191 & 649 & 1 & 1 \\
\hline Kamazou & 12,678 & 1,585 & 2 & 2 \\
\hline Gonin Gora & 17,553 & 2,194 & 3 & 3 \\
\hline Mararraban Rido & 1,154 & 144 & 0.2 & 0.2 \\
\hline Narayi & 46,278 & 5,785 & 7 & 7 \\
\hline Sabon Tasha & 53,270 & 6,659 & 8 & 8 \\
\hline Unguwan Television & 55,407 & 6,926 & 8 & 8 \\
\hline Tsaunin Kura & 2,476 & 309 & 0.3 & 0.3 \\
\hline Unguwan Sunday & 48,670 & 6,084 & 7 & 7 \\
\hline Unguwan Muazu/Kabala West & 64,530 & 8,066 & 9 & 9 \\
\hline Nasarawa & 120,222 & 15,028 & 18 & 18 \\
\hline Kudenda & 1,986 & 248 & 0.3 & 0.3 \\
\hline Unguwan Romi & 18,704 & 2,338 & 3 & 3 \\
\hline Total & 682,625 & 85,309 & 100 & 100 \\
\hline
\end{tabular}

Source: Author's Field Work (2012).

for the study (Table 1).

\section{Data requirement, sources and characteristics}

The data for this study involves Landsat MSS (Multispectral) Satellite image scenes of Kaduna for 1990, 1995 and 2000 at $32 \mathrm{~m}$ resolution, Nigeria-Sat 1 image of 2005 at $32 \mathrm{~m}$ resolution, and Quick Bird image of 2010 at $1 \mathrm{~m}$ resolution. These were obtained from the National Centre for Remote Sensing Jos, Plateau State and the National Space Research and Development Agency (NASRDA), Abuja. Kaduna metropolitan map at scale 1:50,000 was obtained from KASUPDA. Data on the population increases over the years; physical and commuting characteristics between the city centre and the peripheral areas were acquired. Finally, data on the application of development control within the peripheral areas were also obtained through field investigations, which specifically include the spatial characteristics like measurement of the infrastructures within the peripheral areas.

\section{RESULTS AND DISCUSSION}

Spatially, the location of the sampled peripheral areas within Kaduna Metropolis shown in Table 2 indicates that the distance between Rigachikun to the central market which is within the Central Business district is $10.1 \mathrm{~km}$, Rigasa to the central market is $5.4 \mathrm{~km}$, Gonin-Gora is $14.1 \mathrm{~km}$, Narayi is $10.6 \mathrm{~km}$, Unguwan Muazu/Kabala
West is $4.5 \mathrm{~km}$, and Rafin Guza is $8 \mathrm{~km}$, respectively.

To the south of the River Kaduna, the expansion was initially fuelled by industrial growth attracting large numbers of in-migrants. Although many of the textile factories have closed down; the formal and informal opportunities north of the river and the few industrial concentrations south of the river continue to underpin Kaduna's role as one of Nigeria's largest cities, only behind Lagos, Kano and Abuja. North of the river, subsequent to the growth of the new district of Sabon Gari to the west of Tudun Wada, development of the Western districts of Rigasa, Afaka and Ung. Mu'azu was stimulated by the building of the western expressway by the Federal Government in the late 1970s as part of the new North/South trunk road linking Kano, Kaduna, Abuja and a Niger River crossing at Lokoja. Expansion of development to the east has been hampered by lack of access bridges over the Kaduna River. The potential for dramatic change in this pattern of growth has increased with the recent construction of the New Makarfi Bridge and plans for the New Millennium City that opens up the development potential east of the river, as well as the recent award and completion of the Gobarau Road Bridge and approach roads.

The population of the sampled peripheral areas which 
Table 2. Kaduna sampled peripheral areas spatial location.

\begin{tabular}{lc}
\hline Area & Distance from the central market $(\mathbf{k m})$ \\
\hline Rigachikun & 10.1 \\
Rigasa & 5.4 \\
Gonin Gora & 14.1 \\
Narayi & 10.6 \\
Ungwan Muazu/Kabala West & 4.5 \\
Rafin Guza & 8 \\
\hline
\end{tabular}

Source: Author's Field Work (2012).

Table 3. Kaduna sampled urban peripheral areas' transport infrastructure.

\begin{tabular}{|c|c|c|c|c|}
\hline \multirow{2}{*}{ Area } & \multicolumn{2}{|c|}{ Tarred roads $(\mathbf{k m})$} & \multirow{2}{*}{ Untarred roads $(\mathrm{km})$} & \multirow{2}{*}{ Foot-paths (km) } \\
\hline & Good condition & Not in good condition & & \\
\hline Rigachikun & 3.1 & 1 & 5 & 5.4 \\
\hline Rigasa & 4.2 & 6.3 & 4 & 3.6 \\
\hline Gonin Gora & 3.5 & 1 & 5.8 & 3.1 \\
\hline Narayi & 5 & 6.2 & 7 & 3.6 \\
\hline Ungwan Muazu/Kabala West & 5.43 & 6 & 4.65 & 4.3 \\
\hline Rafin Guza & 2 & 2.4 & 4.1 & 3.9 \\
\hline Ungwan Boro & 2 & 4.7 & 4.91 & 2.4 \\
\hline
\end{tabular}

Source: Author's Field Work (2012).

to a large extent was fuelled by the communal clashes in Kaduna in 2000 and 2002 and has had the effect of changing settlement patterns and promoting the expansion of the city in rapidly unplanned residential development in the south (Christian) and the west and north (Muslim). It must be emphasized that these developments are not exclusively one religion or the other. There is still much mixed living in Kaduna's residential areas.

This has propelled the growth of settlements like Afaka, Mando, National Eye Center, Panteka, Rigasa, Bakin Ruwa, Ugwan Muazu, Nasarawa, and Kudenda which hitherto serves as an industrial layout. This has extended until it intersected with the Abuja express way. Towards the eastern part, development in this direction has spread through the road linking NNPC and the East West to Unguwan Boro, Kamazou, Janruwa, Sabon-Tasha, and Rido settlements. It is the largest single concentration of peripheral development in all the direction of growth of Kaduna metropolis. Finally, in the south along Abuja express way, unplanned urban development has reached about $4 \mathrm{~km}$ from the point of express intersection to Goni Gora.

\section{Transport Infrastructure}

The analysis in Table 3 on the transport infrastructures in the sampled peripheral areas indicates that $53 \mathrm{~km}$ of the roads in the peripheral areas are tarred. $25 \mathrm{~km}$ of the tarred roads are in good condition, while $28 \mathrm{~km}$ are in various state of disrepair. Similarly, $35 \mathrm{~km}$ of the roads are untarred and $26.3 \mathrm{~km}$ of the area are being accessed through footpaths.

The number of kilometers of road that are untarred and those areas that are accessed by only footpath compete favourably with those that are tarred and the narrow nature of such roads depicts clearly the absence of plan in the area; and thus, its unplanned outlook. The transport infrastructure of significance in most peripheral areas is the major highways linking Kaduna to other parts of the country in all directions. To the north of the town is the federal trunk "A" highway linking Kaduna, Zaria and Kano. To the west of Tudun Wada, is the western bypass which was constructed by the federal government in the late 1970's as part of the New/South trunk road linking Kano, Kaduna,and Abuja. To the south east, is the road linking Kaduna to NNPC Kachia and then Abuja. Apart from the fact that these highways circulation within the settlements themselves is very poor, most of the roads are not motorable particularly during the raining season.

\section{Social Infrastructure}

Social infrastructure consist of several educational and health institutions. The institutions in the periphery are however only capable of rendering primary and to some 
extent secondary services in these areas. They are however inadequate in terms of quantity and quality to cater for the growing population. The population therefore depends on infrastructure within the town itself. The high rate of population growth and urbanisation has placed a strain on available infrastructure within these areas and on Kaduna town. Some utilities and services, such as electricity, pipe-borne water and fire and postal services are available on skeletal basis. This is shown in Table 4.

The table shows that, there are a wide range of facilities and services that are either absent completely or are inadequate in the sampled peripheral areas. Amongst others, the ones that are absent include the postal agency, civic centre, fire service, recreation ground, and refuse depot. Similarly, those that exist but are inadequate include nursery (65\%), primary school (64\%), secondary school $(57 \%)$, shopping centre $(90 \%)$, police post $(82 \%)$, health centre $(95 \%)$, local market $(79 \%)$, Motor Park $(70 \%)$, commercial bank $(89 \%)$, petrol filling station (33\%), and cemetery (65\%).

This shows that, lack of planning in the peripheral areas have greatly affected the provision of basic facilities and services in the area. For instance, settlements like Rigasa with a population of 149600 can only boast of one secondary school, a nursery and primary school which is far below the standard expected. This means that residents have to travel long distances to meet up with some of their daily needs, especially the schools, shopping and for recreational purposes amongst others, this of course informed the planlessness in those areas.

\section{Commuting between Kaduna metropolis and the peripheral areas}

Daily commuting between Kaduna metropolis and the sampled peripheral areas are influenced by the paucity of infrastructures at the peripheral areas, and to a large extent the unplanned settlements, as most of the commuting were geared towards meeting up with their daily work schedules or for buying some specialized goods and services or the sales of some agricultural produce, which may not all be consumed at the peripheral areas where there are fewer people with less income. Some of the commuters go to the city in search of jobs, as most of the infrastructures that enable job creation are located in the metropolitan area, hence, transportation as a functional variable in the history of a city, plays a significant role in the mass movement of people and goods and services. The functionality of the system is a sign of uniqueness of the city, because people tend to move from one point to the other using roads, rail and water in conjunction with the facilities. The city does not operate intra-city train and water transport systems, the only means of transport is the road (Figure 4).
The survey results in Table 5 on modes, factors of influence and trip frequencies in the sampled areas indicate that the most used mode for commuting between the peripheral areas and the city centre is the bus (24\%), motorcycle $(20 \%)$, private car $(6.8 \%)$, bicycle $(2.6 \%)$ and the least which is the lorry/trailer $(2.1 \%)$, respectively. The major factors of influence for the trips are work $(23 \%)$, religious (12.5\%), medical $(9.5 \%)$, social visits $(6.8 \%)$, commercial activities like shopping (6.8\%), and to source for job (3.5\%). The trips that occur daily has the highest frequency $(28 \%)$, weekly $(16 \%)$, monthly $(8.1 \%)$, occasionally $(5.3 \%)$, seasonally $(3.1 \%)$, and finally annually $(1.5 \%)$, respectively.

The implication of this however, is that people commute from the peripheral areas to the city centre on bus daily for work and spent a lot of time on transit due to traffic gridlocks that are experienced during the morning and evening peak hours, and that could have informed the reason why they had earlier indicated that the mode of commuting to and from the peripheral areas are grossly inadequate and un-conducive compared to the growing population of such areas.

City peripheries are the growth fronts. It is in the peripheries that most rapid physical growth impulses occur either in planned or spontaneous manner. Incidentally, it is one of the ironies of city history that some of the efforts made to cure the evils originally caused by city growth have enabled cities to grow more rapidly. This is particularly true about the provision of utilities like electricity and water to peripheral locations which have the effect of producing accelerated physical developments in the areas affected, which is the true situation of what is happening in Kaduna metropolis.

\section{Conclusion}

Undoubtedly, the peri-urban areas of Kaduna metropolis are fast transforming from an agricultural community to an urban centre and local environmental problems of various magnitudes are becoming prominent. Urgent and coordinated measures must be taken to contain the frightening rate of expansion of the built-up area into adjourning farmlands. The progressive loss of these farmlands to urban use means a continuous reduction of the most valuable agricultural lands in the peri-urban areas. As the metropolis expands, infrastructure requirements continually increase and expand spatially. At present, these are managed by the state agencies or local administrations with no mechanism for overall coordination across the metropolis.

Peripheral areas of Kaduna and the metropolis at large suffer serious traffic congestion caused by the ever increasing number of private vehicles on inadequate road network with finite capacity and hence, the need to enforce compliance with basic development control standards. Specifically, this will involve the upgrading and 
Table 4. Social infrastructure, utilities and services.

\begin{tabular}{|c|c|c|c|c|c|c|c|c|c|c|c|c|c|}
\hline \multirow{3}{*}{ Area } & \multirow{3}{*}{ Population } & \multicolumn{9}{|c|}{ Educational institutions } & \multirow{2}{*}{\multicolumn{3}{|c|}{$\begin{array}{c}\text { Facilities } \\
\text { Commercial bank }\end{array}$}} \\
\hline & & \multicolumn{3}{|c|}{ Nursery } & \multicolumn{3}{|c|}{ Primary } & \multicolumn{3}{|c|}{ Secondary } & & & \\
\hline & & Existing & Standard & Deficit & Existing & Standard & Deficit & Existing & Standard & Deficit & Existing & Standard & Deficit \\
\hline Rigachikun & 19,454 & 2 & 2 & - & 2 & 3 & 1 & 2 & 1 & - & - & 2 & 2 \\
\hline Rigasa & 149,600 & 1 & 15 & 14 & 2 & 10 & 8 & 1 & 7 & 6 & - & 4 & 4 \\
\hline Gonin Gora & 17,353 & 2 & 2 & - & 1 & 2 & 1 & 1 & 1 & - & - & 2 & 2 \\
\hline Narayi & 46,278 & 3 & 5 & 2 & 2 & 4 & 2 & 1 & 2 & 1 & - & 4 & 4 \\
\hline U-Muazu/ K-West & 56,113 & 3 & 6 & 3 & 1 & 5 & 4 & 1 & 2 & 1 & 2 & 5 & 3 \\
\hline Rafin Guza & 9,514 & - & 1 & 1 & 1 & 1 & 1 & - & 1 & 1 & - & 1 & 1 \\
\hline \multirow[t]{4}{*}{ Total (\%) } & 298,312 & 35 & 100 & 65 & 36 & 100 & 64 & 43 & 100 & 57 & 11 & 100 & 89 \\
\hline & & \multicolumn{12}{|c|}{ Facilities } \\
\hline & & \multicolumn{3}{|c|}{ Recreation ground } & \multicolumn{3}{|c|}{ Shopping centre } & \multicolumn{3}{|c|}{ Health centre } & \multicolumn{3}{|c|}{ Refuse depot } \\
\hline & & Existing & Standard & Deficit & Existing & Standard & Deficit & Existing & Standard & Deficit & Existing & Standard & Deficit \\
\hline Rigachikun & 19,454 & - & 2 & 2 & - & 2 & 2 & - & 2 & 2 & - & 2 & 2 \\
\hline Rigasa & 149,600 & - & 4 & 4 & - & 5 & 5 & - & 4 & 4 & - & 6 & 6 \\
\hline Gonin Gora & 17,353 & - & 2 & 2 & - & 2 & 2 & - & 2 & 2 & - & 2 & 2 \\
\hline Narayi & 46,278 & - & 4 & 4 & 2 & 5 & 3 & 1 & 6 & 5 & - & 4 & 4 \\
\hline U-Muazu/ K-West & 56,113 & - & 5 & 5 & - & 6 & 6 & - & 7 & 7 & - & 5 & 5 \\
\hline Rafin Guza & 9,514 & - & 1 & 1 & - & 1 & 1 & - & 1 & 1 & - & 1 & 1 \\
\hline \multirow[t]{4}{*}{ Total (\%) } & 298,312 & 0 & 100 & 100 & 10 & 100 & 90 & 5 & 100 & 95 & 0 & 100 & 100 \\
\hline & & \multicolumn{9}{|c|}{ Civic uses } & \multicolumn{3}{|c|}{ Services } \\
\hline & & \multicolumn{3}{|c|}{ Civic centre } & \multicolumn{3}{|c|}{ Church } & \multicolumn{3}{|c|}{ Mosque } & \multicolumn{3}{|c|}{ Local market } \\
\hline & & Existing & Standard & Deficit & Existing & Standard & Deficit & Existing & Standard & Deficit & Existing & Standard & Deficit \\
\hline Rigachikun & 19,454 & - & 2 & 2 & - & 2 & 2 & 5 & 2 & - & - & 1 & 1 \\
\hline Rigasa & 149,600 & - & 8 & 8 & - & 4 & 4 & 18 & 8 & - & 1 & 4 & 3 \\
\hline Gonin Gora & 17,353 & - & 2 & 2 & 6 & 2 & - & - & 2 & 2 & 1 & 2 & 1 \\
\hline Narayi & 46,278 & - & 6 & 6 & 10 & 5 & - & - & 5 & 5 & 1 & 4 & 3 \\
\hline U-Muazu/K-West & 56,113 & - & 7 & 7 & 2 & 5 & 3 & 7 & 5 & - & - & 5 & 5 \\
\hline Rafin Guza & 9,514 & - & 1 & 1 & 1 & 2 & 1 & 4 & 2 & - & - & 1 & 1 \\
\hline \multirow[t]{3}{*}{ Total (\%) } & 298,312 & 0 & 100 & 100 & 95 & 100 & 5 & 141 & 100 & 41 & 21 & 100 & 79 \\
\hline & & \multicolumn{12}{|c|}{ Services } \\
\hline & & \multicolumn{3}{|c|}{ Motor park } & \multicolumn{3}{|c|}{ Police post } & \multicolumn{3}{|c|}{ Petrol filling station } & & ostal agen & \\
\hline Rigachikun & 19,454 & Existing & Standard & Deficit & Existing & Standard & Deficit & Existing & Standard & Deficit & Existing & Standard & Deficit \\
\hline Rigasa & 149,600 & - & 1 & 1 & 1 & 2 & 1 & 2 & 2 & - & - & 1 & 1 \\
\hline Gonin Gora & 17,353 & 1 & 2 & 1 & 1 & 4 & 3 & 2 & 8 & 6 & - & 2 & 2 \\
\hline
\end{tabular}


Table 4. Contd.

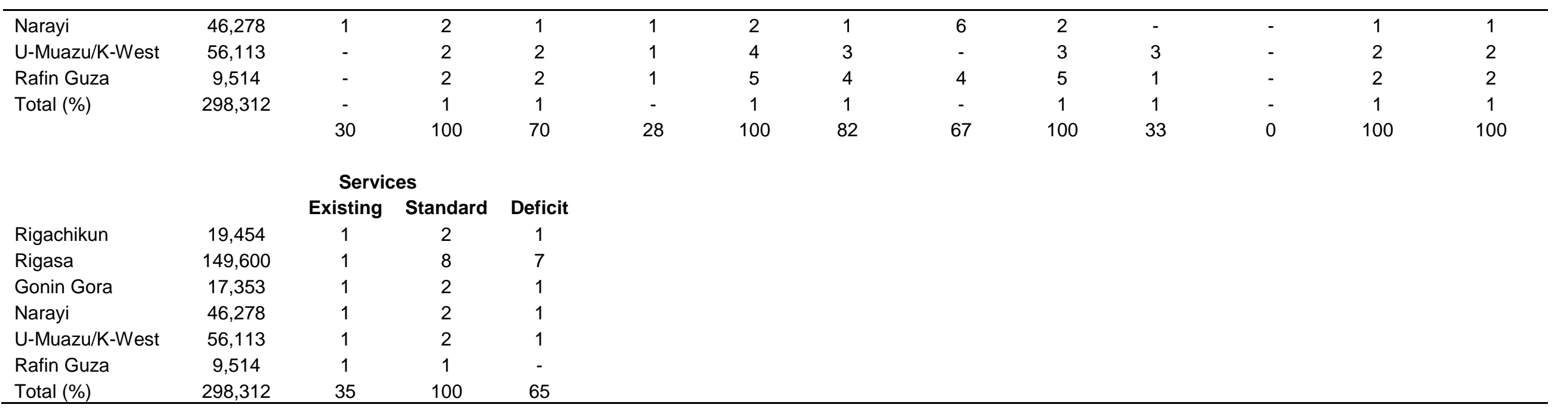

Table 5. Modes, factors of influence and trip frequencies of peripheral areas in relation to Kaduna City Centre.

\begin{tabular}{|c|c|c|c|c|c|c|c|c|c|c|c|c|c|c|c|c|}
\hline \multirow[b]{2}{*}{ Traffic origin } & \multirow{2}{*}{$\begin{array}{c}\text { Total No. of } \\
\text { people } \\
\text { interviewed }\end{array}$} & \multicolumn{6}{|c|}{ Modes } & \multicolumn{6}{|c|}{ Factors of influences } & \multicolumn{3}{|c|}{ Trip frequencies } \\
\hline & & Bus & $\begin{array}{c}\text { Private } \\
\text { car }\end{array}$ & Lorry/Trailer & Taxi & Motorcycle & Bicycle & Work & $\begin{array}{l}\text { Commercial } \\
\text { goods }\end{array}$ & $\begin{array}{c}\text { Job } \\
\text { seeking }\end{array}$ & $\begin{array}{l}\text { Social } \\
\text { visits }\end{array}$ & Education & $\begin{array}{l}\text { Newspaper } \\
\text { circulation }\end{array}$ & Daily & Weekly & Monthly \\
\hline Rigachikun & 120 & 52 & 21 & 7 & 18 & 20 & 2 & 20 & 7 & 30 & 22 & 32 & 2 & 86 & 32 & 2 \\
\hline Rigasa & 935 & 489 & 96 & 15 & 132 & 185 & 18 & 444 & 154 & 177 & 111 & 39 & 10 & 779 & 147 & 14 \\
\hline Narayi & 290 & 138 & 82 & 4 & 23 & 40 & 3 & 148 & 55 & 45 & 21 & 8 & 13 & 205 & 73 & 12 \\
\hline U-Muazu/K-West & 350 & 144 & 85 & 4 & 73 & 42 & 2 & 164 & 97 & 42 & 21 & 12 & 14 & 255 & 86 & 9 \\
\hline Gonin-Gora & 110 & 53 & 34 & 1 & 16 & 6 & 1 & 48 & 20 & 23 & 12 & 3 & 4 & 80 & 27 & 3 \\
\hline Rafin- Guza & 60 & 25 & 10 & 4 & 12 & 8 & 1 & 28 & 14 & 12 & 3 & 1 & 2 & 45 & 13 & 2 \\
\hline
\end{tabular}

Source: Author's Field Work (2012).

extension of transport infrastructure to the peripheral areas, promotion of the use of public transport by improving and extending the range and coverage of services and the use of technology to advertise car sharing and carpooling on all modes and discourage the use of private vehicles by the introduction of congestion charges, financial disincentives, regulations and other similar interventions. This will improve the capacity of the road networks in a manner consistent with international traffic management measures.

\section{RECOMMENDATION}

The world is experiencing one of the fastest rates of urbanization ever recorded; the experience has been unique in scale, pervasiveness and in historical antecedents. Several cities continue to expand their spatial boundaries to the peripheries in order to cater for high population growth and migration. Although the expansion of cities is unavoidable under strong developmental pressures, the increasingly uncoordinated manner 


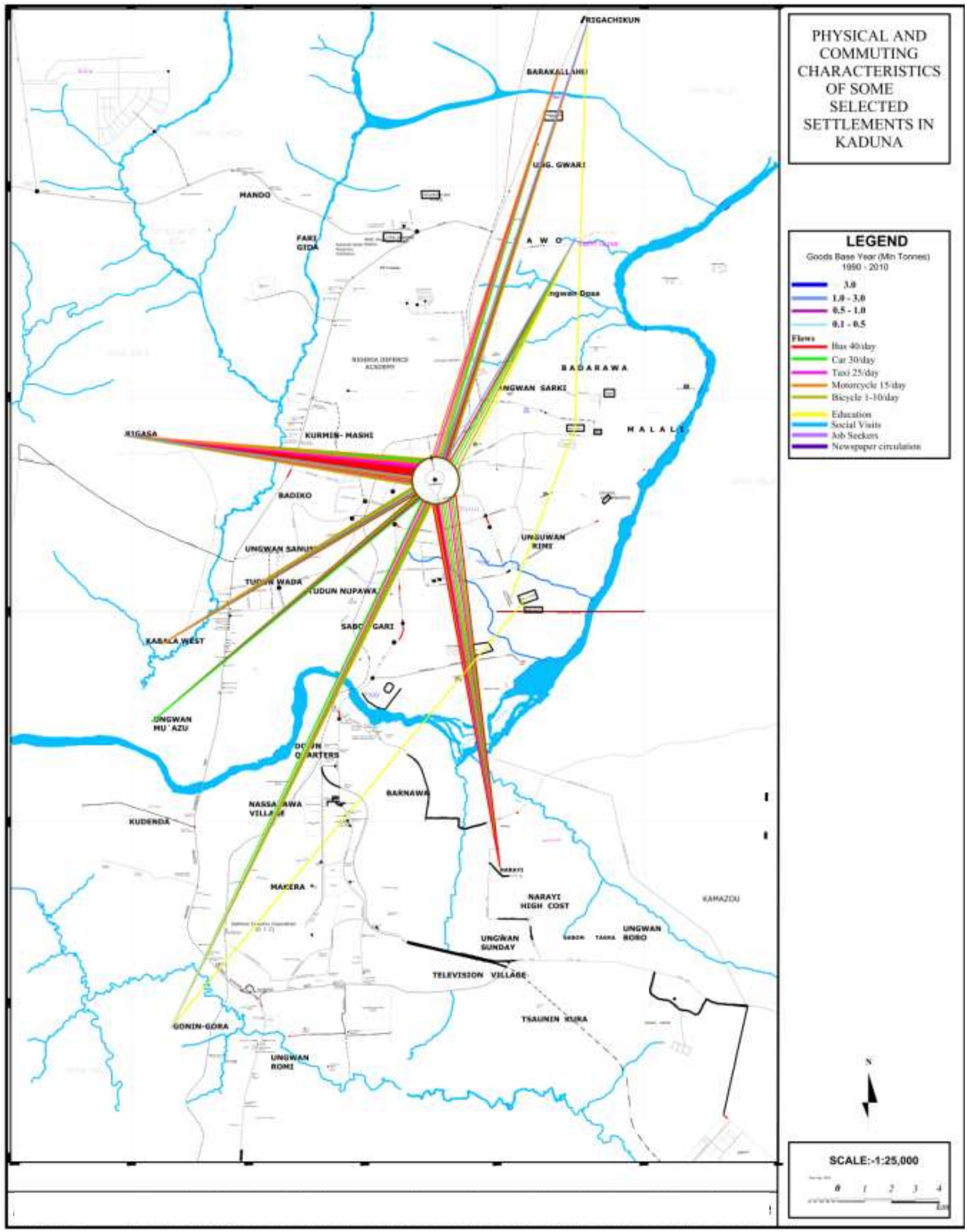

Figure 4. Flow analysis: Peri-urban areas in relation to the city centre. 
particularly in developing countries of these expansions has induced the spill over of environmental degradation across metropolitan areas. These problems are enormous and varied. Millions have been left to live for prolonged periods in makeshift urban slums, suffering from poverty of income, health, nutrition, and safety. Constant threats of food and water scarcity have been brought about by climate change, unsustainable resource use, and inadequate planning. Cities are increasingly unsustainable vulnerable and insecure, and therefore achieving sustainability and resilience for cities has to be high on any government's agenda.

Ecosystem services can address many of the challenges that cities increasingly face, clean air, safe drinking water, and protection from climate change effects are all highly relevant to human development in cities, and many forms of poverty are caused or exacerbated by a lack of access to these ecosystem services. Furthermore, cities consume tremendous amounts of resources and thus generate large amounts of waste and emissions. These negative externalities of urban growth are borne disproportionately by the income poor, who do not have access (or the means) to procure clean drinking water and health services. The role of natural areas in providing catchment for stable and cheap drinking water cannot be overemphasized; almost a third of the 100 largest cities have proximate natural areas that provide this service. Furthermore, green spaces in or near cities also deliver services such as air purification, temperature regulation, groundwater recharge, and cultural services including aesthetics and recreation, all leading to healthier lifestyles. Urban biodiversity and ecosystems deliver myriad other benefits, from underpinning social and economic development to climate change mitigation and adaptation. Wetlands can treat storm water runoff and also offer biodiversity and recreational services. Local food production in cities is an exciting and evolving dimension of cities, and it can both decrease the emissions externality of cities and also improve food security. Restoration and management of near shore ecosystems such as mangroves can reduce impacts of storm surges, decrease climate change vulnerability, and increase resilience. It is recognized that urban consumption patterns not only adversely impact nearby ecosystems but also ecosystems further away: urban teleconnections and the ecological footprint of cities are geographically dispersed and indeed immense. However, cities cannot be viewed as problematic merely because they form a large consumer base. They also hold the key to changing production and resource used by decreasing waste production, increasing recycling, and moving citizens to more sustainable forms of consumption. Furthermore, energy-efficient and renewable-energy infrastructure development through economies of scale can reduce emissions. Ecological infrastructure in cities regulates local temperatures and buffers the effects of urban heat islands. For example, water areas buffer temperature extremes by absorbing heat in summertime and by releasing it in wintertime (Chaparro and Terradas, 2009). Likewise, vegetation reduces temperature in the hottest months through shading and through absorbing heat from the air by evapotranspiration, particularly, when humidity is low (Hardin and Jensen, 2007). Water from the plants absorbs heat as it evaporates, thus cooling the air in the process (Nowak and Crane, 2000). Trees can also regulate local surface and air temperatures by reflecting solar radiation and shading surfaces, such as streets and sidewalks that would otherwise absorb heat. Decreasing the heat loading of the city is among the most important regulating ecosystem services trees provided to cities (McPhearson, 2011).

Technological improvements, which enhance longevity of life through medical advancement has contributed to the continued increase in population. The population structure of most developing countries is broad based, meaning there are more young people who are likely to migrate to the area of opportunities hereby increasing the population of these areas. The demand and increase in car ownership and improvement in the public transport system enable both low and high income earners to move from their work places in the city centre to the periphery. Distance to a large degree no longer inhibits the decision to reside at the periphery. It has been observed that with the improvement in mass transport system low income groups could also afford to commute to and from the peri-urban areas. In cities like Kaduna, peripheral areas grow at a very fast rate along major transportation corridors, highways and railway lines. This has brought about the growth of settlements like Jere, Katari, Rijana and Tafa amongst others along the Kaduna-Abuja Expressway. Similarly, settlement like Rigasa is witnessing rapid growth with the completion of the Abuja-Kaduna standard gauge railway project which is currently in operation has gone a long in easing the movement of people goods and services to and from the two areas as most people opts for the railway transportation as against the road with attendant security challenges like arm robbery and kidnapping.

Carpooling and carsharing service or urban lift-sharing services which involves the sharing of car journeys so that more than one person travels in a car by matching services that bring people together who are travelling in the same direction to share private vehicles for particular journeys. Similarly, carsharing involves short-term automobile rental services intended to substitute for private vehicle ownership and making an affordable and occasional use of a vehicle: several users share the access to a car fleet, which is owned and managed by a service provider. They use advanced technologies (e.g. matching software, the internet and optional call centres) for trip matching, increasing the potential to reach critical mass of users. Carpooling and carsharing reduces each person's travel costs such as fuel costs, tolls, reduces 
congestion, pollution, demand for parking and even the stress of driving; it is also seen as a more environmentally friendly and sustainable way to travel.

Kaduna is one of the biggest cities in Nigeria that is perennially plagued by traffic gridlocks that could last hours on end. Carpooling or ride-sharing is undoubtedly the key to easing the already critical traffic situation which would give back to commuters, the hours of manpower and productivity that are lost to traffic each day. Though, elements of carpooling and ridesharing exist in most motor parks in Kaduna metropolis and Nigeria in general, but the mode of operation and the timely availability of these rides have failed to achieve the desired results simply due to inconveniences and delays inherent in the present system. However, with burgeoning technology, with more and more people utilizing and engaging technology several platforms like Uber and NG-Ride bookings emerging to boost carpooling and ridesharing services. Not only is technology a smart use of resources, it is the future of transportation in Nigeria. Nevertheless cities are buying more energy efficient cars to curb carbon emissions, new transport trends have now become an important ally in that regard.

\section{CONFLICT OF INTERESTS}

The authors have not declared any conflict of interests.

\section{REFERENCES}

Alabi MO (2009). Urban Sprawl, Pattern and Measurement In Lokoja, Nigeria. Theor. Emp. Res. Urban Manage. 4(13):158-164.

Adesina A (2007). Socio-Economic Transformation and the Urban Fringe Landscape in Developing Countries. Paper Presented at the UN Institute for Environment and Human Security Summer.

Aitieri L, Cocchi D, Pezzi G, Scott EM, Ventrucci M (2014). Urban sprawl Scatter Plots for Urban Morphological Zones Data. Ecol. Indic. 36:315-323.

Ashafa AY (2004). Kaduna State: A Cultural View. Kaduna State Newscope 1:1922.

Avram S (2009). The position of ruran-urban fringe in the framework of human settlement system. Forum Geografic Year 8(8):139-145.

Badiane A (2006). African Cities: Some thesis for a New Beginning. Minna: Kings Plaza Publishers.

Bello AL (2000). Kaduna State in Nigeria: People United, Future Assured. Federal Ministry of Information and National Orientation 2:249-262.

Belal AA, Moghanm FS (2011). Detecting Urban Growth Using Remote Sensing and GIS Techniques in Al-Gharbiya governorate, Egypt. Egypt J. Remote Sens. Space Sci. 14:73-79.

Bryant CR, Russwurm LH, McLellan AG (1982). The City's Countryside: Land and its Management in the Rural-Urban Fringe. London: Longman.

Chaparro L, Terradas J (2009). Ecological Services of Urban Forest in Barcelona, Centre de Recerca Ecologica i Applications Forestalls. Universitat Autonoma de Barcelona Belleterra.

Douglas I (2006). Peri-Urban Ecosystems and Societies Transitional Zones and Contrasting Values. In D. McGregor, D. Simon \& D. Thompson (Eds.), Peri-Urban Interface: Approaches to Sustainable Natural and Human Resource Use. London, U.K: Earthscan Publications Ltd. pp. 18-29
Hardin PJ, Jansen RR (2007). The Effect of Urban Leaf Area on Summertime Urban Surface Kinetic Temperatures: A Terre Haute Case Study. Urban Forestry and Greening 6:63-72.

Hogrewe W, Joyce SD, Perez EA (1993). The Unique Challenge of Improving Peri-Urban Sanitation; Bureau for Research and Development, USAID, WASH Task No 339.

Liu Y, Lv XJ, Qin XS, Guo HC, Yu YJ, Wang JF, Mao GZ (2007). Anintegrated GIS based analysis system for land-use management of lake area sin urban fringe. Landsc. Urban Plan. 82:233-246.

Long H, Tang G, Li X, Heilig GK (2007). Socio-economic driving force so fland- use change in Kunshan, the Yangtze River Delta economic area of China. J. Environ. Manag.83:351-364.

Mabogunje AC (2008). The Inclusive City: Popular Empowerment of Local Government in a Rapidly Urbanizing African. J. Niger Institute Town Planners (NITP), Ibadan 21(1):1-17.

Mahmoud MI, Duker AB, Conrad AC, Thiel CB, Ahmad MB (2016). Analysis of Settlement Expansion and Urban Growth Modelling Using Geoinformation for Assessing Potential Impacts of Urbanization on Climate in Abuja City, Nigeria. Remote Sens. 8:220 doi:10.3390/rs8030220

Max L (1967). Kaduna Master Plan, London: Faber.

McPhearson PT (2011). Toward a Sustainable New York City: Greening through Urban Forest Restoration." In Sustainability in America's Cities: Creating the Green Metropolis, edited By M. Slavin, 181-204. Washington, DC: Island Press.

National Population Commission (2006). Population Census of the Federal Republic of Nigeria. Analytical Report at the National Level, National Population Commission, Abuja.

National Population Commission (NPC) (2016). Nigerian 2016 Census Provisional Results. National Population Commission, Abuja.

Nowak DJ, Crane DE (2000). The urban forest effects (UFORE) model: Quantifying Urban Forest Structure and Functions. In M. Hansen and T. Burk (Eds), Integrated Tools for Natural Resource Inventories in the $21^{\text {st }}$ Century. St. Paul: North Central Research Station. pp. 714720.

Sanusi YA (2010). Water, Sanitation and Human Development in Urban Fringe Settlements in Nigeria. Theoretical and Empirical Researches in Urban Management. pp. 14-29.

Saxema A (2008). Monitoring of urban fringe areas using remote sensing and GIS techniques; Retrieved February 09, 2010, from GIS development.org.

Simon D, McGregor D, Thompson D (2006). Contemporary Perspectives on the Peri-Urban Zones of Cities in Development Areas, in Peri-Urban Zones of Cities in Development Areas. In: D. McGregor, D. Simon and D. Thompson, Peri-Urban Interface: Approaches to Sustainable Natural and Human Resource. London, UK: Earthscan Publications Ltd. pp. 3-17.

Taleshi M (2009). Informal settlements, and sustainable urban development case study: metropolis of Mashhad in Notheastern Iran'. World Appl. Sci. J. 10(7):1235-1238.

Tibaijuka AK (2006). A Message from the Executive Director. Habitat Debate 12(2):12.

Umaru TE (2006). An Analysis of the Spatial Pattern of Occurrence of Meningococcal Meninigiatis in Kaduna State of Nigeria Between 1999-2003. An Unpublished M.Sc. Thesis Submitted to the Department of Geography, Obafemi Awolowo University, lle- Ife, Osun State.

Wolch JR, Byrne J, Newell JP (2014). Urban Green Space, Public Health and Environmental Justice: The Challenge of Making Cities Just Green Enough'. Landsc. Urban Plan.125:234-244. 